\title{
ベトナム国におけるハンセン病流行状況調査 および関連施設訪問を終えて
}

\author{
山崎 利雄* \\ 国立感染症研究所ハンセン病研究センター
}

〔受付：2002年 6 月 5 日〕

キーワード：国際共同研究事業、ベトナム社会主義共和国

国際共同研究事業によるハンセン病の疫学調査 のため、同僚の福富さん、甲斐さんと私の三人 で、平成14年 2 月28日からから 3 月 8 日までの 9 日間べトナム社会主義共和国を訪問した。出発 日、成田出発予定時間は 9 時50分であるので、飛 行機に乗り込んだ。ところが、一人の客待ちのた め、成田空港を出発したのが、10時半頃であっ た。私たちは、香港経由でハノイに向かう予定で あったが、香港で乗り換えに 1 時間しかないの に、30分も遅れたため、スチュワーデスさんに頼 み最初に飛行機を下ろしてもらい、何とかハノイ 行きの飛行機に間に合った。飛行機は順調に飛行 し、定刻にハノイの空港に到着した。空港には、 3 年前にハンセン病研究センターに来ていたJICA の元研修生テュオンさんが迎えに来てくれてい た。彼の車でハノイ市内のホテルまで送っても らった。車の空から見るベトナムの風景は、ベト ナム戦争の傷跡を全く感じさせず、私が幼いころ 見ていた田園風景が広がっていた。牛に鋤を引か せて田を耕している人、牛に荷物を乗せ、田のあ ぜ道をのんびり歩いている人、田の草取りをして いる人などが視界に入ってきて、すっかり感傷に

*Corresponding author :

国立感染症研究所ハンセン病研究センター 干189-0002 東京都東村山市青葉町 4-2 - 1

TEL : 042-391-8211 FAX : 042-394-9092

E-mail : toshiyam@nih.go.jp
浸っていた。まさに文部省唱歌に出てくる「ふる さと」の歌詞を思い出させるそんな風景であった

(写真 1)。ところが、ハノイ市内に近づくにつ れてバイクの数が増えてきた。車よりもバイクの 方が多く、また、道路交通法があるのか？と疑り たくなるような運転であった。歩行者優先である 日本とは全く違い、道を横切るときには、命がけ の思いをした。しかし、現地の人はバイクの洪水 の中を平気で道を横切っていた。ホテルに着いて 荷物を置いた後（写真 2)、テュオンさんに居酒 屋の様なところに連れていってもらい夕食をとっ た。加熱したものをロにしていたが、器や箸が気 になった。夕食後、ホテルに戻る迄の間に、靴磨 きの少年、花売り少女、物ごいのお年より等が来 て、日本との経済力の違いをまざまざと見て心が 痛んだ。ようやくホテルに戻り、慌ただしかった 初日が終わった。

3 月 1 日から 3 月 3 日までハノイに滞在し、 テュオンさんの所属している国立バックマイ病院 皮虚性病科研究所 (National Institute of Dermatovenereology Bach Mai Hospital : NIDV) を訪問 した（写真 3 ）。所長さんは、不在であったが、 副所長他 4 名の方々が応対してくれた。NIDV は、保健省直轄で、ベトナムのハンセン病対策の 総元締めをする機関であった。ベトナム全土に19 の療養所と 2 病院があり、この病院は、ベトナム 北部地区の拠点であった。保健省直轄のNIDVの 下にベトナムでは、MDTが1983から開始され、 
1995年以降では100\%行われるようになった。罹患 率は、人口 1 万人あたり 6.78 人（1983年）から、 0.2人（2000年）になっている。また、ハンセン病 の新患者数は、1358人（1999年）といったハンセ ン病の現状について教えて貪った。午後、ハノイ 市内の見学に出かけた。玉山柌、文廟を見学し た。文廟近くを歩いていて、偶然通りかかったガ イドブックに載っていない露店が軒を連ねる食べ 物市場にいった。ハノイ市民のために野菜や果 物、肉や魚などいろいろな種類の食材が豊富に売 られていた。活気があり、鶏や鳩、ウサギなど生 きたまま取引され、日本では、お客に見せない屠 殺場面や、羽もぎ、皮剥ぎや解体の工程などを、 若い女性や小学生くらいの女の子たちが、店の前 や横で行っているのを目撃して少しショックを受 けた。

夕方、テニオンさん御夫婦にタイ湖（西湖）近 くのレストランへ連れていってもらい、いろいろ なベトナム料理をご馳走になった。特に日本では ほとんど食べられなくなった夕ニシを食べ懐かし い味を思い出した。味付けは、日本人に向いてい ると感じたが、衛生面が多少気になったので、野 菜を豊富にだされたが、加熱したものしか口にで きなかった。お腹が一杯になり10時ころホテルに 戻った。

3 月 2 日は土曜日で、病院や役所は休みのた め、朝 9 時にホテルを出発し、車で田園地帯を一 路世界遺産の一つであるハロン湾へ向かった。途 中の景色は、私が育った 35 年前の田舎を思い出さ せるものであった。途中バイクの籠に豚の頭を入

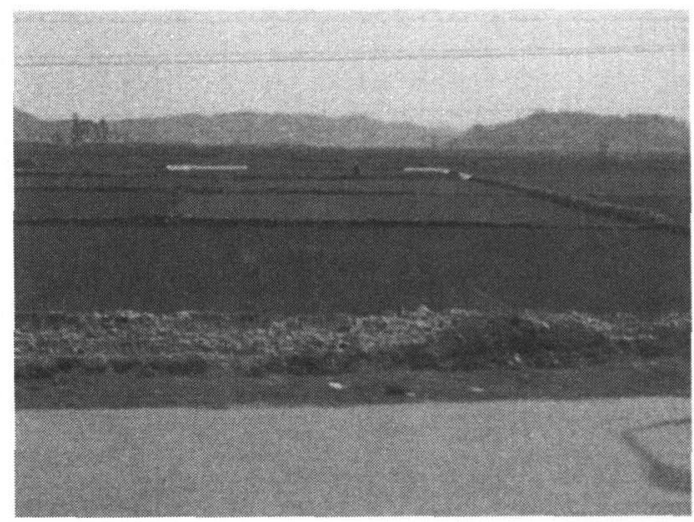

写真 1 田園風景。豊かな田園風景が延々と続く。
れ、胴体をバイクのステップに乗せて運んでいる 人や、 2 人乗りをし、後ろに乗っている人が、風 呂で使うかき混ぜ棒のような器具を使い、水をか き混ぜ、空気を送り込みながら生きた魚を運んで いたり、ハリネズミの様に荷物を満載した自転車 に載っている人、田から仕事を終えてのんびりあ ぜ道を歩いて家路につく人など、沢山の見慣れな い光景を見ることが出来た。ハロン湾のバイチャ イに着き、ハロン湾クルーズを行うために、船に 乗り达もうとしたところ、係の人に止められた。 テュオンさんに買ってもらった乗船券は、ベトナ ム人用で、外国人は料金を 2 倍払うシステムに なっているらしいと後で教えてもらった。すばら しい海上の島々の景色や洞窟を歩いて楽しんで、 約 4 時間後、元の場所に戻ってきた。夕方 5 時こ ろハロン湾を後にし、ハノイ市内を目指した。し かし、とても怖い運転をする人が運転手だった。 彼は、かつて米軍の空襲にひるまず、ホー・チ・ ミンルートを使い物資を運んでいた強者で、とて も素晴らしい（恐ろしい）運転だった。何度とな く対向車線を平気で走って前の車を追い越した。 前方から来る車を危機一髪でかわす。とても目を 開けて前方を見ていられなかった。途中のドライ ブインで夕食を取った。調理場が見えていたが、 トイレのすぐ側で野菜や食器などを洗っていた。 ハノイでもトイレの側で食材の準備をしていたの で、衛生観念が日本人と違うのだと実感した。ま た、食器をほとんど洗わない、ただ紙でぬぐって いるだけであった。ここでも習慣の違いを痛感し た。従って私は、加熱した料理しかロにすること

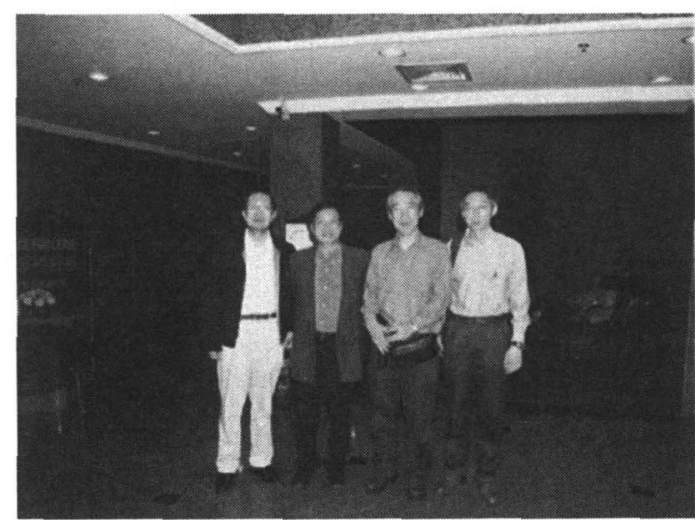

写真 2 ハノイのホテルのロビーにて（右から甲斐さん、 福富さん、テュオンさん、筆者） 
ができなかった。ようやく 9 時半ころホテルにも どり、そのまま、多分精神的疲れのせいで、シャ ワーも浴びず眠ってしまった。

3 月 3 日は、朝 9 時にホテルを出て、テュオン さんの車でホー・チ・ミン廟へ向かった。途中で テュオンさんの従兄弟だという軍人を一人乗せ た。ホー・チ・ミン廟へ着いたとき沢山の人がな らんで順番を待っていた（写真 4 ）。ところが、 警備兵の責任者にテュオンさんの従兄弟が話しを したら、警備兵は私たちを、列の前の方に連れて 行き、割り込ませた。早く来て順番を待っている 人たちに悪いと思いながら見ていると、私たちと 同様なことをしている人たちがいて、さらに列の 前の方に割り込んでいた。軍人および知人は、優 遇措置を受け、しかも、紹介した人の階級により 差があるようであった。しかし、警備兵は、それ を当然と考えているようで、何か嫌な気分になっ た。建物の中は、寒いくらい冷房が効いて、あち こちに警備兵が立っていた。部屋の中央には、べ トナムの民族的英雄ホー・チ・ミン主席の遺体 が、ガラスケースに入れられて安置されていた。 遺体の顔は、まるで眠っているかのように安らか で、早朝からたくさんの人々が会いに訪れたくな るほど優しい顔をしていた。建物を出てから ホー・チ・ミンが住んでいた家、ホー・チ・ミン 博物館、バーデン広場、軍事博物館（写真 5 ）、 歴史博物館と回った。いずれも、悲しいベトナム の歴史、侵略者を跳ね返した国民の意志が伝わっ てきた。タ方ホテルの近辺を散策した。路上で子 供が果物を売っていた。小さなリンゴを購入し、

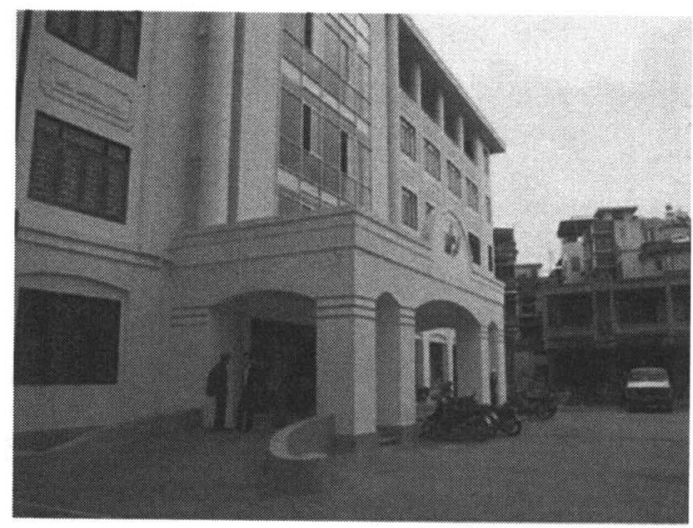

写真 3 NIDVの建物。NIDVは、ベトナムにおけるハン セン病対策の総元締めをする機関である。
代金を支払ったが、後ほど地元の人に聞いてみた ところ、地元の人に売る価格の 5 倍もの料金を支 払わされていた。また、福富さんと一緒に、街で 出会った話し好きな老人の家に招待され、お茶を 御馳走になった。ベトナムのお年寄りは、英語を ほとんど話せない人が多いのに、彼は、流暢な英 語で話をした。元外交官で、いろいろな国に住 み、大使までして定年退職し、そこに住んでいる らしい。ベトナムでは裕福な部類に入るのだろう が、そこは社会主義国なので大豪邸には住んでい なかった。話しの端々に反米的発言がみられ、依 然としてベトナム戦争の心の傷跡が深いことを感 じた。しかし、とても親日的な人であった。

3 月 4 日はクイニョンに移動するために、早朝 5 時にホテルを出発し、ハノイの空港へ向かっ た。ホー・チ・ミンへ向かう飛行機が、客待ちの ため40分も遅れて、ハノイの空港を飛び立った。 私たちは、クイニョン行きに乗り換えなくてはな らないが、飛行機の出発時間が迫っているので、 ここでもスチュワーデスさんにお願いして、優先 的に降ろしてもらい、乗り継ぎ場所へ急いだ。ク イニョン行の飛行機は、50人程度しか乗れない小 さなプロペラ機であった。無事離陸、順調に飛行 し、クイニョン空港に着陸したが、飛行機が本質 的に嫌いな私は、生きた心地がしなかった。クイ ニョンの空港はとても小さく、飛行機から建物ま で約 $100 \mathrm{~m}$ 歩いた。到着ロビーも出発ロビーもな く、小さな駅の待合室みたいなロビーらしきもの があっただけであった。のどかでのんびりとした 空港であった。クイニョンには、元研修生トウン

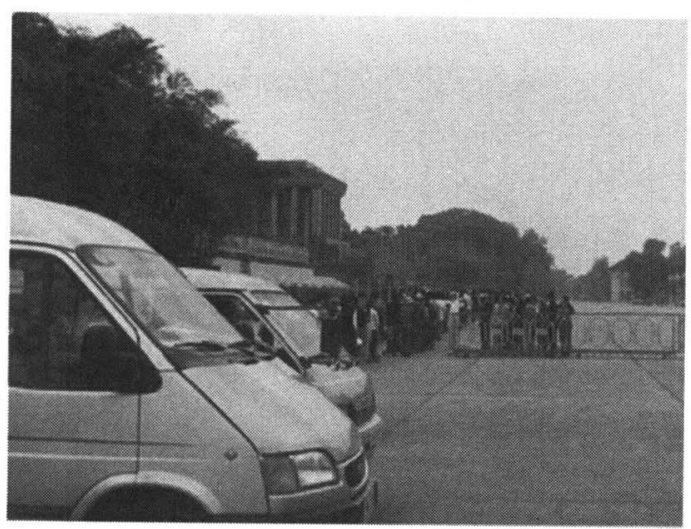

写真 4 ホー・チ・ミン廟に入るために順番を待つ人々 
さんとブイさんという 2 人がいて、トウンさんが クイニョン空港まで出迎えに来てくれていた。彼 の車で、クイニョン市郊外にあるトウンさんとブ イさんが勤めているハンセン病皮虐・性病科病院 の宿泊施設 (写真 6) に送ってもらった。宿泊施 設は、海辺にあり、とても景色の美しい場所で あった。一休み後、宿泊施設近くの病院内の食堂 で、副所長のタイさんと共に夕食会が開かれた。 タイさんとは、福富さんがインドの日米環太平洋 国際会議で知りあいになったらしく、宴会がとて も盛り上がった。夕食後は、宿泊施設に戻ってき た。回りに街灯は、ほとんど無く、海にはイカ釣 り漁船の灯がたくさん見えた。病院の敷地内に住 むハンセン病患者の漁師さんが、漁をしているの だとトウンさんは言っていた。空には無数の星が 輝いていた。しばらくテラスで夕涼みをしなが ら、夜景を眺め、部屋に戻った。部屋には冷房設 備があったので、公を開けなくても良かったが、 どこからかイモリが数匹入ってきて、天井にへば りついていた。また、蚊帳があり、何十年ぶりか で蚊帳をつった。風呂は無く、共同のシャワーは 冷水で、しかも、トイレの中に設置されていた。 鍵はかかるが、冷水を浴びる気にならずそのまま 眠ってしまった。

3 月 5 日の早朝、まだ暗いのに外がざわついて いたので目が覚めた。テラスから外を見ると、病 院の敷地内に暮らしている患者さんの子供達が、 スクールバスを待っているところであった。しば らくして太陽が水平線から上がってくるのを見る ことが出来た。とても美しい景色で感動した。朝

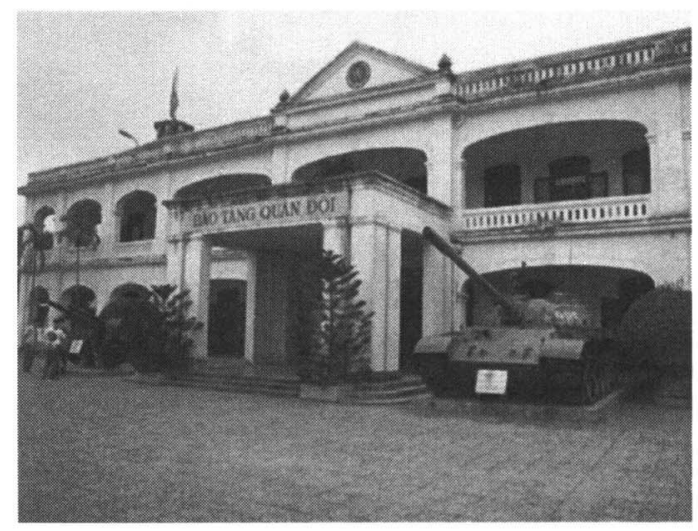

写真 5 軍事博物館の建物
食まで、海辺を散歩して帰ってきたが、その間に 何人かのハンセン病患者さんにあった。彼らは、 海辺の掃除をしていた。9 時ころから、病院の会 議室に行き、病院の説明を聞き、われわれの訪問 の目的を伝えた。この病院は、NIDVの下部機関 で、ベトナム中部地区の拠点であり、ハンセン病 療養所などの 10 施設（山岳地方 3 施設、海岸地方 7 施設）を統括している。30人の医師を含め 190 人のスタッフで 200 床のベッド数であり、1999年 ハンセン病療養所から皮虐科・性病科病院となっ た。会議終了後、病院の施設を見学した。研究所 の設備は、PCR機、シークエンサー、最新の機械 や、数はないが、かなりしっかりしていた。PCR の原理から講義を行わなければならなかったが、 とても意欲的なスタッフ陣であった（写真 7 ）。 ハンセン病棟も見学し、入院中のハンセン病患者 さんに会った。義手や義足を作っている患者さ ん、患者さんにあったサンダルを作っている人、 リハビリを懸命に行っている患者さんなどに会わ せて鿓った（写真 8$)$ 。ハンセン病に冒されなが ら眯命に生きている姿に感動した。夕方、記念撮 影をした（写真 9) のち、食堂で夕ン所長以下ス タッフが、歓迎パーティーをしてくれた。昨夜以 上に盛り上がり、とても楽しい一時を過ごした。 海辺ということで生ガキや魚の刺し身を出してく れた。ついに断りきれず生ものをロにしたが、そ の晚は平気であった。

3 月 6 日朝、トウンさんとの朝食会と国際共同 で仕事をするために、長期滞在には宿泊に問題あ りということで、ホテルの当たりをつけるため

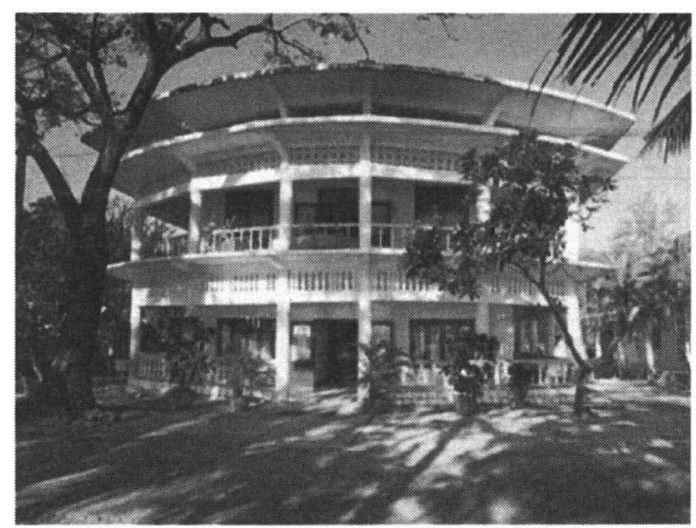

写真 6 クイニョンの病院内にある宿泊施設の建物 
に、クイニョン市内に出かけた。私は、朝からお 腹の調子が悪くなり、我慢できなくなったので、 私だけ薬をとりに宿泊施設にもどり、薬を飲んで から再びクイニョン市内へ向かい同僚たちと合流 した。長期滞在に使えそうなホテルを見つけた が、そこから、病院まで通う為には、車かバイク を使わざるを得ないのが問題であった。市内視察 終了後、再び宿泊施設に戻り、所長、副所長、2 人の元研修生に挨拶をし、夕方クイニョンから再 びホー・チ・ミン市に移動した。ホー・チ・ミン の空港には、また別の元研修生ファンさんに出迎 えてもらい、ホテルまで彼の車で送ってもらっ た。ホー・チ・ミン市は、かつて南ベトナムの首 都で、サイゴンと呼ばれていた街だけに、商業中 心都市で、ハノイよりも大きな街で高層ビルも沢 山あった。人やバイクや車の数も多かった。バイ クで道を逆行して走ってきたり、クラクションを

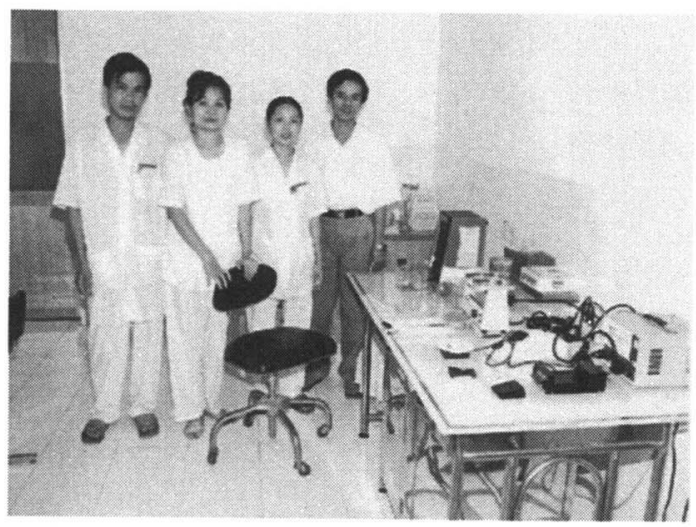

写真 7 トウンさんと検查室のスタッフの皆さん。

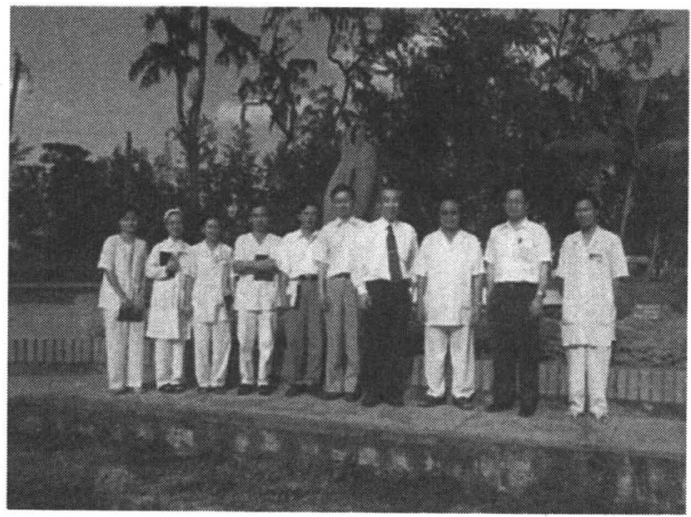

写真 9 クイニョンの病院の皆さんとの記念撮影（右から検 査技師長、筆者、タン所長、福富さん、甲斐さん、 トウンさん、フィさん、検査室の 3 人の女性)
鳴らし、歩行者がいようが関係なく、突進してき たりするのにはビックリした。午後7時ころ、ホ テルに着いた。部屋に荷物を置いてロビーで同僚 たちと待ち合わせたが、ホテルの中で道に迷って しまうほど大きなホテルであった。夕食を食べに 街に出たが、道路を横断するときは命がけであっ た。夕食後クイニョンではシャワーすら浴びられ なかったので、ゆっくりと風呂に入った。朝から お腹の調子が悪かったので早めに眠った。

3 月 7 日朝、甲斐さん、福富さんもお腹をやら れていた。原因は、昨日クイニョンの喫茶店で飲 んだアイスティーの様であった。特に福富さんは 辛そうであった。しかし、午前中ベンビエンブー 病院を訪問した（写真10）。この病院は、ファン さんが現在勤務している病院で、昨年アメリカの 企業の援助で建てられた一般病院であった。現在 は18の診療科に150床の規模で、80人のスタッフ

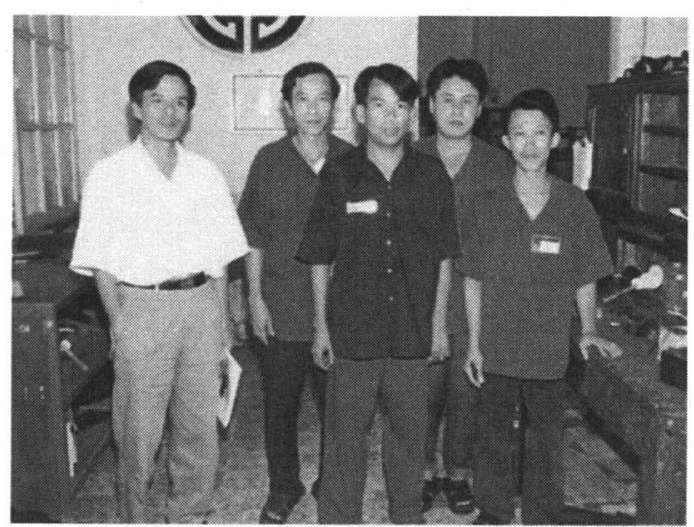

写真 8 トウンさんとハンセン病患者さんたち。（靴、サ ンダル作製の作業場にて)

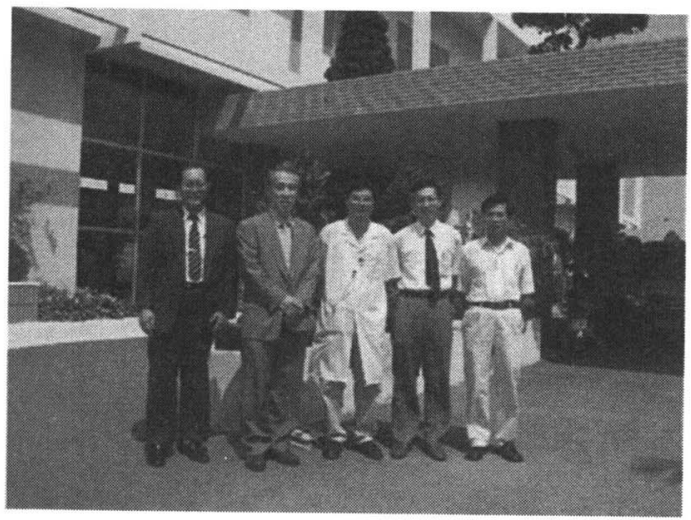

写真10 ベンビエンブー病院にて。（右からファンさん、 甲斐さん、タイ病院長、福富さん、筆者) 
がいるが、将来は 180 人に増やすと言っていた。 最初に病院内を案内してくれた。一般病院のた め、手術室、レントゲン室、検査室等を見せてく れた。建物は新しく綺麗であったが、機械類は古 く、特にレントゲン装置は年代物で、本当に正確 な写真が撮れるのか疑問であった。その後、会議 室にもどり、病院長、 2 人の副院長他、 5 名の人 が出席し、国際共同研究が可能かどうかの話し合 いがもたれた。私の印象では、一般病院のため、 われわれの目的にはそぐわないと感じた。

昼食は、ファンさんの家に招待され、たくさん のベトナム料理で歓待を受けた。しかし、私は昨 日よりだいぶ回復していたが、同僚二人が体調を 崩していたのと、料理が多過ぎたため、歓待に充 分答えられなかったのは申訳なかった。午後は、 ホー・チ・ミン市皮膚科病院を訪問した。この病 院は、ファンさんの紹介してくれたベトナムの南 部地域を統括する病院で、 5 つの研究室を持って いた。毎日約 800 人の患者が、皮膚病、STD、ハ ンセン病の外来を訪れている。これまで、フラン ス、カナダとの共同研究をして、サイトカインや
Nramp 等の仕事で J. Infec. Dis. 等に $5 \sim 8$ 報の 発表していた。PGL-1を使った診断技術、PCRに よる迅速診断、らい反応について共同研究をした いし、大学との慗がりもあるので、教育もしたい と言っていた。

タ方ホテルにもどり、帰国の準備をした。皆、 体調がよくなかったので、ホテルのロビーの椅子 に座って体調の回復を待った。午後 9 時頃に ホー・チ・ミン空港に向かい、深夜 0 時 30 発の飛 行機に乗った。 4 人の元研修生に大変お世話に なった事を感謝するとともに、ベトナムでは、 1995年にWHOの基準ではハンセン病が制圧され たことになっている。しかし、クイニョンで会っ た若い患者さんたちは、今なお病気と闘ってい る。日本国内でも、ハンセン病と戦っている患者 さんがいる現実を、決して忘れてはならないと再 認識しながら帰国の途についた。成田には 3 月 8 日の午前 7 時 40 分定刻に着いた。荷物を受け取 り、同僚とはそれぞれ帰る方向が異なるので、空 港で別れ、11時ころようやく家に着き、ベトナム 出張は終わった。 